\title{
Mountain Products. A Lot of Opportunities for Romanian Food Producers
}

\author{
Dumitrache Bogdan Bratoveanu ${ }^{1}$, Raluca Bianca Costea (Voinea), Jiries Mansour ${ }^{3}$ \\ and Silvius Stanciu ${ }^{4}$ \\ 1)2)4) "Dunărea de Jos" University of Galați, Galați, Romania. \\ 3) The Bucharest University of Economic Studies, Bucharest, Romania. \\ E-mail: bbratoveanu@ugal.ro; E-mail: office@go-smart.ro \\ E-mail: jiries.mansour@gmail.com; E-mail: sstanciu@ugal.ro
}

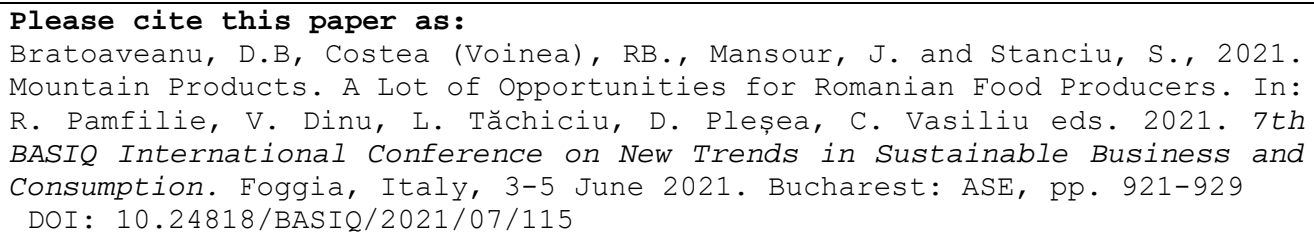

\begin{abstract}
"Mountain product" is a quality scheme recommended BY European Commission to differentiate products obtained in mountainous areas from conventional products. Romania has favourable conditions for the exploitation of this niche market, and national officials have offered support to producers, starting with consultancy services, as well as funds dedicated to the sector. The necessary information has been collected from the publications of the relevant ministry and the national agency with responsibilities in the field.

The research highlighted the national potential in this field, as well as an upward dynamic of the number of certified products. Although the costs of obtaining it is higher, the food produced in mountain areas has specific qualities, due to its special production conditions, and as a result, it can build an opportunity for Romanian producers. The research results can be seized by businesses, which can invest in the mountain agriculture, altogether with the Romanian officials, who can take the most appropriate measures to support the mountain producers.
\end{abstract}

Keywords: Mountain Product, OQT, opportunities, Romania.

DOI: $10.24818 / B A S I Q / 2021 / 07 / 115$

\section{Introduction}

According to Euromontana (2021), mountain agriculture accounts for about $18 \%$ of agricultural holdings, $15 \%$ of agricultural areas and uses about $15 \%$ of the agricultural workforce in this sector at European level. Due to the difficult geographical conditions, the practice of agriculture in the mountainous area involves higher costs, and labour productivity is lower, on average by $28 \%$, compared to disadvantaged areas, and by $40 \%$ compared to lowlands. Mountain farming is characterized by the predominance of small farms, generally below the national mean average, characterized by specialized productions, with high quality products. Animal farms are frequently encountered, being fed mainly through grazing and permanent fruit crops (orchards, vineyards). Agriculture is the basis of the local economy, being closely linked to other sectors: agri-food industry and tourism. The population in the mountainous area carries out a diversified activity, and the number of very small farms is large, especially in the Carpathian Mountains, where semi-subsistence 
agriculture is predominant. Optional quality term (OQT) "Mountain product" is a quality scheme created at European level to differentiate a food product obtained in difficult conditions in European mountain areas from conventional products.

The inclusion of a certain food product in this category is associated in the consumer's mind with the image of a high-quality product, with certified origin, obtained in an area with a low degree of pollution (Stanciu, 2014). The mountain product category includes a wide selection: milk and dairy products, meat and meat-based products, fruit and canned food, pastries, mineral water or even medicinal plants. Mountain products have specific characteristics, due to the particular production conditions in high altitude areas, the environment, the natural resources used and the traditional techniques, alongside with knowledge used in their production and processing (Gheorghe, Nistoreanu and Filip, 2013). The specific production conditions lead to the formation of special quality characteristics for mountain products, noticed by the consumer especially from a sensory point of view.

From a geographical perspective, Romania has favourable conditions for the development of the mountainous production sector. Romania's mountainous area comprises about $33 \%$ of the national territory and 27 counties with large agricultural areas, as well as 3,354,041 inhabitants, representing $15.08 \%$ of Romania's population. Of these, about 2.1 million are found in farming families, 1.3 million identifying as active farmers. There are 815,000 agricultural holdings, of which 254,348 have been registered in the Single Farm Identification Register as of 2016 (Scarlat, 2017). In the local food tradition, the consumption and production of mountain foods are intertwined with the history of the Romanian people, being homemade and consumed at the household level or intended for the small communities in the Carpathian Mountains (Stanciu, et al, 2019).

According to the decision of the Ministry of Agriculture and Rural Development MADR Nr. 5/2017 (MADR, 2017), mountain products are foods intended for human consumption, in which the processed raw materials, respectively feed for farm animals come mainly from mountain areas. In the case of processed products, processing also takes place in mountain areas. Mountain products are promoted in the digital environment by the National Agency for Mountain Areas, created especially to support producers in high altitude areas, and by other public institutions (National Agency for Mountain Areas, 2021).

The decision of MADR and the Ministry of Regional Development and Public Administration (MDRAP) No. 97/2019 (MADR and MDRAP, 2019) defines the criteria for classifying the administrative-territorial units in the mountain area. Thus, the mountainous area is characterized by natural limitations of agricultural productivity, which lead to a lower agricultural production, due to unfavourable climatic and biophysical conditions necessary for the optimal development of agricultural activities.

According to the earlier mentioned ministerial decision, for the delimitation of the mountain area is used a general criteria related to physical conditions (altitude and average slope limitations), membership of the Carpathian Convention (the administrative-territorial units with $50 \%$ of their territory within the Carpathian Convention are included), obtaining a combined limit score, inclusion as a mountain area within the Territorial Development Strategy of Romania, or the criterion of continuity of the mountain area (MADR and MDRAP, 2019). At the European level, it has been adopted a common definition of the term quality product: "mountain product", which can be used in the labelling of agricultural products. The term may be used only for products for which feed and raw materials come mainly from mountain areas and for which their processing also takes place in mountain areas. According to Santini, Guri and Gomez Y Paloma (2013), there will be derogations from the European Commission (EC) to Regulation (EU) no. 1151/2012 of the European Parliament and of the Council of 21 November 2012 on quality schemes for agricultural products and foodstuffs.

The authors consider that it is necessary to take into account the specificity of the sectors involved in mountain production, the adaptation of regulations on the place of origin of feed, the places where agricultural raw material produced in mountain areas is shaped into processed food, or the share of non-mountainous ingredients found in a processed mountain product, which can be considered acceptable to maintain the character of a mountain product. Appropriate means should be used for the application of the rules and to ensure coexistence between the term "mountain product" and other 
existing instruments, such as trademarks and geographical indications (EC, 2012). In the absence of derogations, the applicability of the optional quality term "mountain products" could be affected.

\section{Materials and methods}

Clarivate Analytics, SCOPUS, Google Scholar and ResearchGate databases were used for bibliographic documentation. For specialized information in the legislative field, the regulations of MADR, MDRAP and other national regulations on mountain products were consulted. At the European level, the rules adopted by the European Commission have been used, in particular Regulations on quality schemes and Regulations on mountain products. The data provided by Euromontana was used for the analysis on mountain products at the European level. At the Romanian level, the registrations of certified mountain products were found in the Mountain Product section within the Ministry of Agriculture and Rural Development, where it was established a National Agency for Mountain Areas, an institution specialized in providing consulting services to mountain producers. The collected data was processed, graphically represented and interpreted. The results were then compared with other information from the existing literature.

\section{Results}

The term "mountain product" was protected by Regulation (EU) no. 1151/2012, which was subsequently supplemented by the European Commission through the Commission Delegated Regulation (EU) No 665/2014. Since 2014, some European countries have started to implement Community legislation at the national level. The optional quality "mountain product", currently recognized throughout the European Union, aims to help producers better promote their products in a dynamic and competitive European market (Nagy and Dabija, 2020). Romania benefited from the involvement of the officials in expending the potential of the mountain products sector, and as a result, it is currently one of the most active Member States involved in the development of mountain products' certification. Romanian mountain production represents almost $0.7 \%$ of mountain production in Europe. The mountainous regions of Romania are areas with an important economic, social, cultural and environmental potential. Furthermore, Romania is one of the most active SM in the development of OQT in its mountainous areas. In addition, a series of funds were allocated for the mountain area through the National Rural Development Program 2014 - 2020 (PNDR 2020), the total amount being estimated to over 683 million euros intended for financing investments.

Euromontana Report (2017) states that Austria has directly applied Community legislation, without adapting it to national specificities, while Romania, France Germany, Italy, Slovenia, the Czech Republic, Bulgaria and Croatia have adapted/are in the process of adapting national legislation to European Commission regulations (Table 1).

Table no. 1. Mountain products in Europe (selected countries).

\begin{tabular}{|l|l|l|l|c|}
\hline Country & $\begin{array}{c}\text { Mountain } \\
\text { area (\%) }\end{array}$ & $\begin{array}{c}\text { UAA/ } \\
\text { Mountain } \\
\text { Area (\%) }\end{array}$ & \multicolumn{1}{|c|}{$\begin{array}{c}\text { National Agency/ } \\
\text { Control System }\end{array}$} & $\begin{array}{c}\text { Mountain Product } \\
\text { Label/Products (e.g) }\end{array}$ \\
\hline Austria & 73.4 & 54.7 & $\begin{array}{l}\text { Ministry of Health / Ministry of } \\
\text { Agriculture }\end{array}$ & Almmilch \\
\hline France & 23.1 & 18.3 & $\begin{array}{l}\text { Directorate-General for Competi- } \\
\text { tion, Consumer Affairs and Fraud } \\
\text { Control }\end{array}$ & $\begin{array}{c}\text { Mont Lait, } \\
\text { Origine Montagne, }\end{array}$ \\
\hline Germany & 2.4 & 1.8 & Federal Government & no information \\
\hline Italy & 47.5 & 33.8 & Ministry of Agriculture & $\begin{array}{c}\text { Latteria CISSVA of Capo di } \\
\text { Ponte, Latteria di Chiuro, }\end{array}$ \\
\hline Romania & 29.9 & 19.7 & $\begin{array}{l}\text { Mountain Area Agency/ Ministry } \\
\text { of Agriculture and Rural Develop- } \\
\text { ment }\end{array}$ & $\begin{array}{c}\text { National Logo/ } \\
\text { 1840 products }\end{array}$ \\
\hline
\end{tabular}




\begin{tabular}{|l|l|l|l|c|}
\hline Slovenia & 63.2 & 52.9 & $\begin{array}{l}\text { National Administration for Food } \\
\text { Safety, Veterinary Sector and Plant } \\
\text { Protection }\end{array}$ & $\begin{array}{r}\text { 1 producer/ } \\
\text { 1 product }\end{array}$ \\
\hline $\begin{array}{l}\text { Czech } \\
\text { Republic }\end{array}$ & 20.4 & 11.4 & $\begin{array}{l}\text { State Veterinary } \\
\text { Administration/Czech Agriculture } \\
\text { and Food Inspection Authority }\end{array}$ & no information \\
\hline Bulgaria & 38.1 & 7.9 & Regional Food Safety Directorate & no information \\
\hline
\end{tabular}

According to Euromontana, most manufacturers are registered in Italy, closely followed by Romania. There was insufficient data on mountain producers in the other states presented in the table at the time of the study.

\section{Mountain products in Romania}

The disadvantaged mountain area of Romania represents a special geographical area of national interest, with an economic, social, cultural and environmental potential. In line with European policies and the principles of sustainable development, these areas should benefit from a specific, well-defined policy in support of local communities (Nagy and Dabija, 2020). According to the Order of MADR and MRDPA No. 97/2019 (MADR and MDRAP, 2019) 948 territorial administrative units in Romania were included in the category "mountain townships" (figure 1). The delimitation was made on 5 lawbased criteria. Due to the fact that in some situations, administrative-territorial units which were surrounded by mountainous areas did not meet all 5 criteria, an exception was put in place, resulting in the so-called "non-mountain islands". As a consequence of this exception, 10 more administrativeterritorial units were included in the mountain area. The counties call signs were used in figure 1, according to Abrevieri.ro (2021).

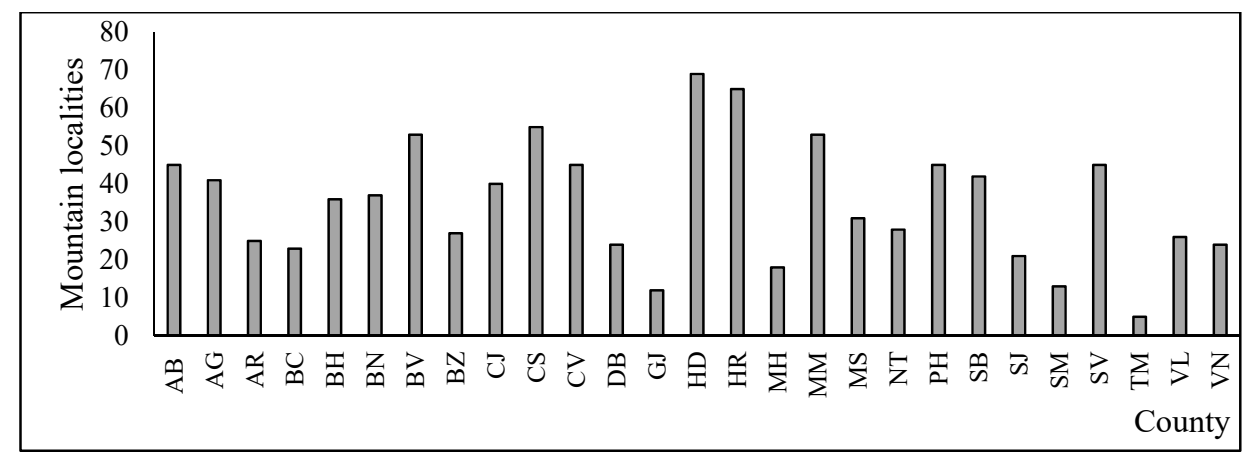

Figure no. 1. Mountain localities in Romania

Source: Authors, by using MADR and MDRAP, 2019

Of the 27 counties presented in figure 1, most mountain townships are classified based on general Criterion 1 (physical conditions related to altitude and slope) being located in the proximity of the Carpathian Mountains. The counties of Hunedoara (69), Harghita (65) and Covasna (55) have the highest number of mountainous townships, while Timișoara (5), Gorj (12) and Satu Mare (13) occupy the last positions. By ATU categories, villages (835 units) are predominant, followed by cities (83) and municipalities (29). A territorial unit was included in the category of component township (figure 2). 


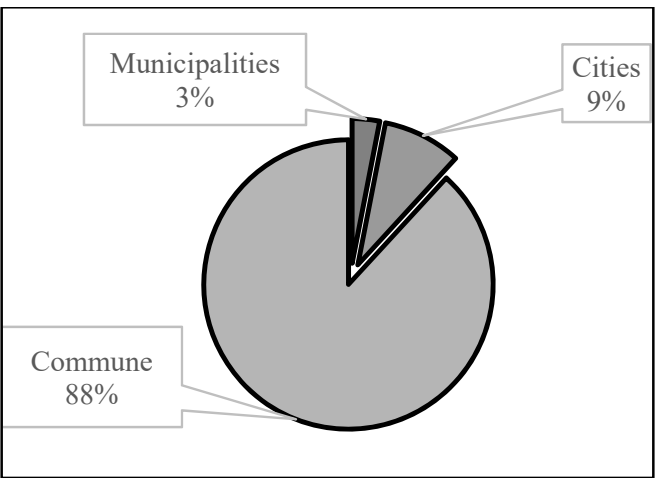

Figure no.2. Distribution of mountain localities by categories Source: Authors, by using MADR and MDRAP, 2019

The National Agency for Mountain Areas (ANZM) has been operating in Romania since 2018, and was established in accordance with the provisions of the Mountain Law no. 197/2018 and H.G. NO. $1036 / 2018$, by reorganizing the Mountain Area Agency. Their agency is based in Vatra Dornei and is directly subordinated to the Ministry of Agriculture and Rural Development. The main attributions of ANZM are related to the support of the mountain areas in Romania, geographical areas marked by specificity, ecological fragility and economical and social disadvantage (ANZM, 2018). MADR introduced a page specially allocated to mountain products (MADR, 2017), in the section "European Quality Systems and Geographical Indications". Available on the website is the Good Practice Guide, focused on the right to use the optional quality statements "Mountain product", together with statistical data on the registration of nationally certified products. The evolution of the number of products accredited at the national level is presented in figure 3.

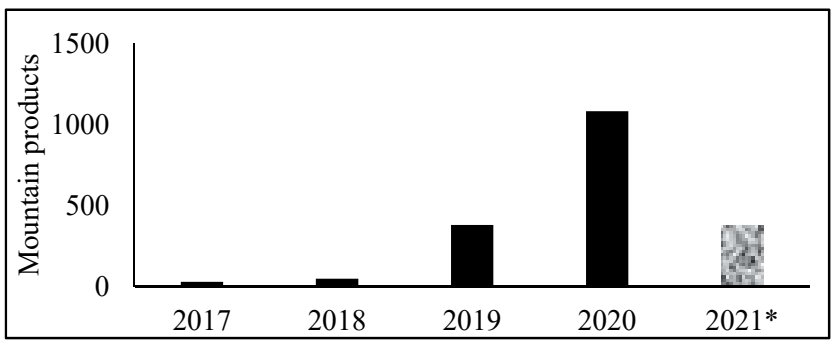

Figure no.3. Mountain products certified in Romania Source: Authors, by using MADR, 2021

At the time of the research, 1915 products were registered on the MADR website. Only the first four months of the current year are available for analysis. Following a humble start in the beginning of the implementation of specific legislation in Romania, with only 9 products registered in 2017, the number of certified products doubled in 2018, and it has exponentially increased in the next period, leading to a total amount of 1540 products being certified in 2020. Looking at counties individually, in 2020 most products were registered in Bistrița Năsăud (72), followed by Maramures (44) and Hunedoara (39). Timiş and Bihor however, have only one registered product (figure 4). 

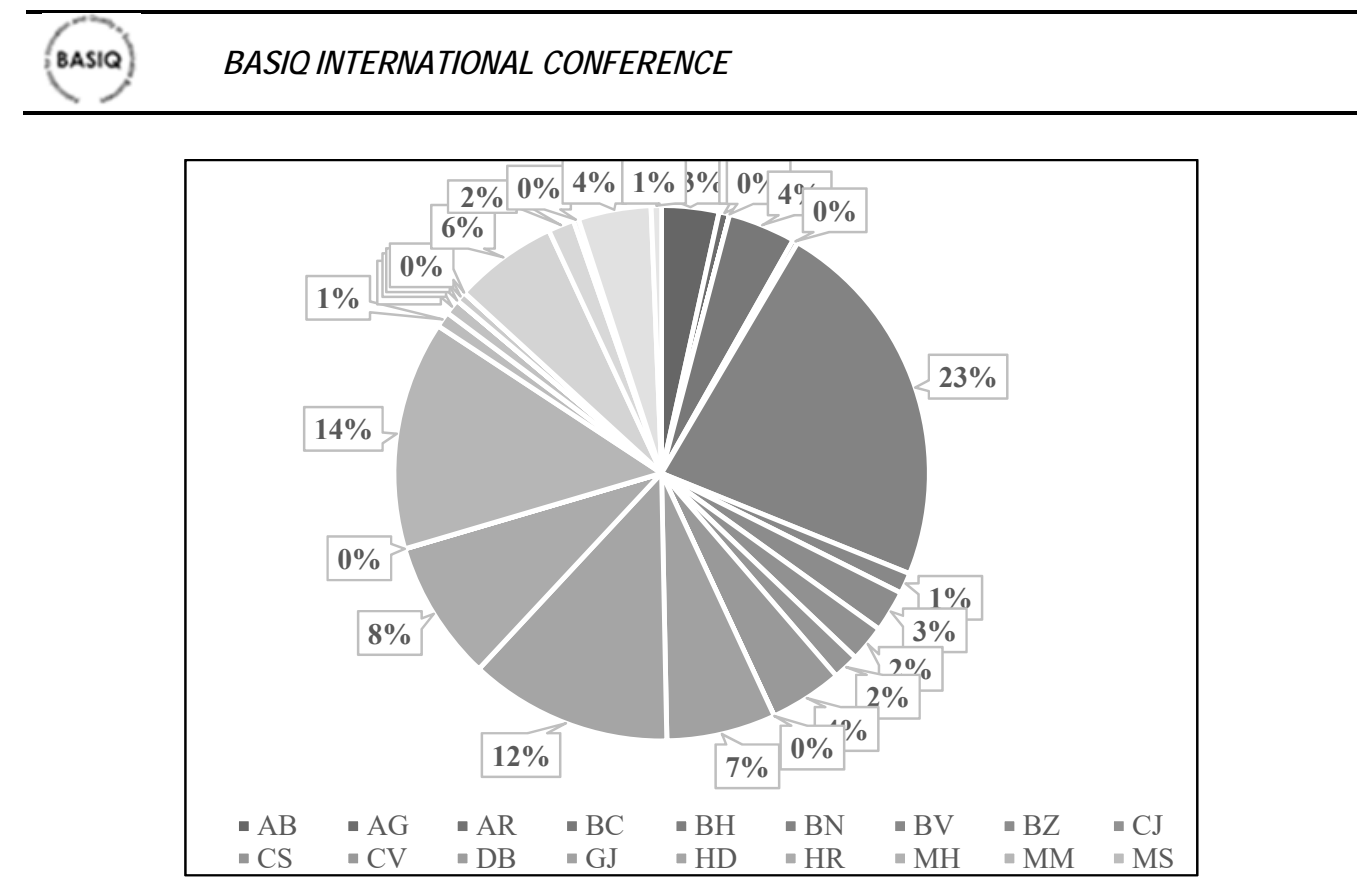

Figure no.4. Share of mountain product records, by counties (2020) Source: Authors, by using MADR, 2021

By product categories in 2020, the registrations of Vegetable Products are predominant (44\%), followed by Milk and Dairy Products (29\%), Bee Products and Vegetables - Fruits (11\%) (figure 5). Romania's meat production does not follow a positive trend in mountain areas, the market being largely dependent on imports (Stanciu et al. 2015).

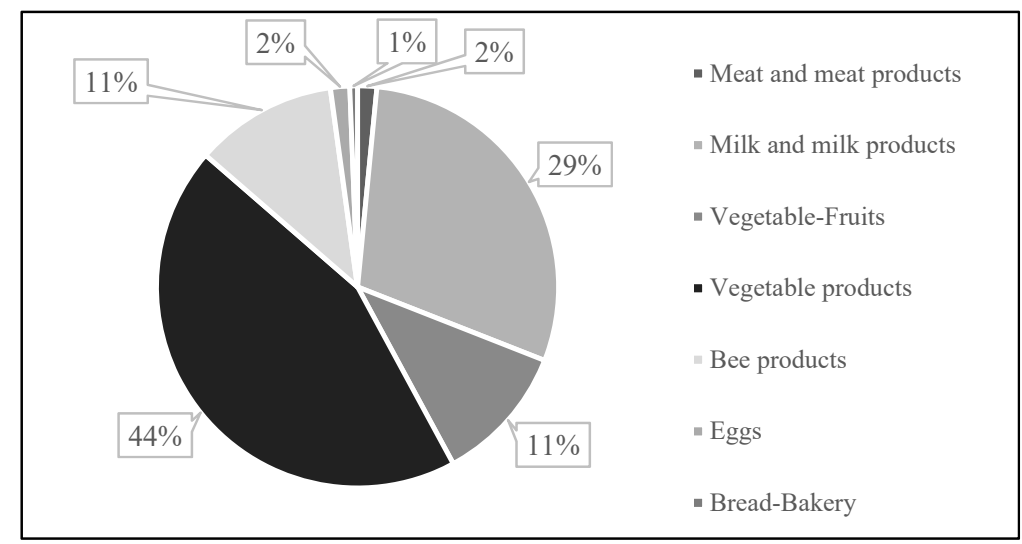

Figure no.5. Share of mountain product records, by categories Source: Authors, by using MADR, 2021

The last positions were occupied by bread - bakery products (2\%), Meat and meat products (2\%) and Eggs (2\%). Some of these products have also been registered as organic products.

According to the specifications of the "Guide of good practices regarding the granting of the right to use the optional quality statement “, MOUNTAIN PRODUCT (MADR, 2017) (figure 6). 


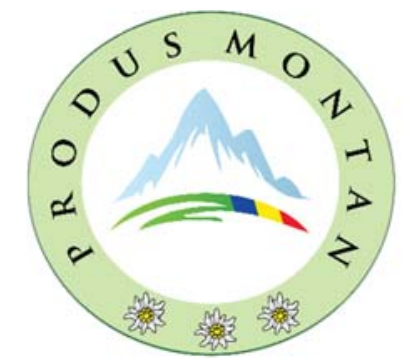

Figure no.6. "Mountain product" logo

Source: Taken from ANZM, 2021

Mountain products shall be labelled in accordance with the provisions of Regulation (EU) No 1169/2011 of 25 October 2011 on informing consumers about foodstuffs. The label of products registered at the National Register of Mountain Products shall bear centrally, under the name of the product, the statement of optional quality "mountain product" and the position in the register. Products that are registered with the optional quality label "mountain product" shall be marked with a national logo, the exclusive property of the National Agency for Mountain Areas, with a minimum size of 15 $\mathrm{mm}$ in diameter (Figure 6). With respect to the marketing of mountain products, the economic operator must comply with all the conditions for the food marketing, in accordance with the legislation in place. It is mandatory to display a photocopy of the decision to grant the right to use the indication of optional quality at the market place, i.e. mountain product ", in the National Register of Mountain Products (R.N.P.M.).

The consistent verification of the market regarding the proper labelling of the products that have been granted the right to use the optional quality indication "mountain product" is made by the National Authority for Consumer Protection, in compliance with the provisions of Regulation (EU) no. Regulation (EC) No 1169/2011 of the European Parliament and of the Council of 25 October 2011 on informing consumers about foodstuffs.

\section{Conclusions}

In order to protect European producers in mountain areas, an optional quality scheme "Mountain product" was proposed in 2014, which can contribute to preserving the tradition of production and consumption of local products in mountain areas. EU Regulation 1144/2014 for the promotion of European agricultural products is the basis of the current policy in the field of mountain products, offering existing funds available for the development of projects since 2015. Although the protection process has started in some countries, it is still in its early stages at the European level. Romania has registered a positive evolution in the adoption of European legislation in the field of mountain products, becoming, along with Italy, the Member State with the most certified mountain products. There is a strong upward trend in the certification of Romanian mountain products, due to the support measures provided by national officials, in a community context.

However, significant incentives should be given to domestic mountain producers to encourage the use of OQT so that they are involved in product certification and promotion. Favourable European regulations and available funds can be an important opportunity for Romanian mountain producers to develop their OQT products and brand.

\section{Aknowledgements:}

This work is supported by the project ANTREPRENORDOC, in the framework of Human Resources Development Operational Programme 2014-2020, financed from the European Social Fund under the contract number 36355/23.05.2019HRD OP /380/6/13 -SMIS Code: 123847. 


\section{References}

Abrevieri.ro, 2021. Indicatives of the counties in Romania, [online] Available at: $<$ http://abrevierile.ro/colectii/indicative-judete-romania> [Accessed 10 April 2021].

Euromontana, 2017. Implementation of the EU optional quality term "mountain product": where do we stand in the different Member States? [pdf] Available at: $<$ https://www.euromontana.org/wpcontent/uploads/2017/04/2017-National-Level-Article-Follow-up-of-the-implementation-of-theEU-OQT_EN-FINAL.pdf> [Accessed 30 March 2021].

Euromontana, 2020 (updated). Implementation of the EU Optional Quality Term "Mountain Product", Where Do We Stand in the Different Member States? [pdf] Available at: $<$ https://www.euromontana.org/wp-content/uploads/2020/06/2020-05-26-Implementation-of-theOQT_EN.pdf> [Accessed 12 April 2021].

Euromontana, 2021. Mountain farming and rural areas in Europe, [online] Available at: $<$ https://www.euromontana.org/en/working-themes/agriculture-and-rural-development $>$ [Accessed 02 April 2021].

European Commission EC, 2012. Regulation (EU) No 1151/2012 of the European Parliament and of the Council of 21 November 2012 on quality schemes for agricultural products and foodstuffs, Official Journal of the European Union, [online] Available at: <https://eur-lex.europa.eu/legalcontent/EN/TXT/?uri=CELEX\%3A32012R1151> [Accessed 10 April 2021].

European Commission EC, 2014. Commission Delegated Regulation (EU) No 665/2014 of 11 March 2014 supplementing Regulation (EU) No 1151/2012 of the European Parliament and of the Council with regard to conditions of use of the optional quality term 'mountain product', Official Journal of the European Union, [online] Available at: <https://eur-lex.europa.eu/legalcontent/EN/TXT/PDF/?uri=CELEX:32014R0665\&from=en $>$ [Accessed 10 April 2021].

Gheorghe, G., Nistoreanu, B.G. and Filip, A., 2013. Traditional products - vectors of sustainable development on the regional and national markets. Amfiteatru Economic, 15(Special Issue 7), pp.645-658.

Ministry of Agriculture and Rural Development MADR and Ministry of Regional Development and Public Administration (MDRAP), 2019. Order MADR and MDRAP No. 97/2019 on the approval of the classification criteria and the list of localities in the mountain area, [online] Available at: $<$ https://lege5.ro $>$ [Accessed 02 April 2021].

Ministry of Agriculture and Rural Development MADR, 2017. Order of the Ministry of Agriculture and Rural Development MADR Nr. 5/2017 on the approval of the Procedure for verifying the conformity of the data contained in the specifications in order to grant the right to use the optional quality label "mountain product" and to verify compliance with European and national legislation by economic operators who have obtained the right to use of that entry, Published in the "EUROLEX" Database. [pdf] Available at: <https://www.madr.ro/docs/indalimentara/2019/produs-montan/ORDIN-Modificat_-52-2017-modif-31.05.2019.pdf> [Accessed 11 April 2021].

Ministry of Agriculture and Rural Development MADR, 2021. Mountain Product, [online] Available at: $\quad<$ https:/www.madr.ro/industrie-alimentara/sisteme-de-calitate-europene-si-indicatiigeografice/produse-agricole-si-alimentare/produs-montan.html> [Accessed 01 May 2021].

Nagy, I.D. and Dabija, C., 2020, The Transition from Natural/Traditional Goods to Organic Products in an Emerging Market. Information, 11(4), Article number: 227.

National Agency for Mountain Areas ANZM, 2018. About National Agency for Mountain Areas, [online] Available at: <http://azm.gov.ro/despre-noi> [Accessed 02 April 2021].

National Agency for Mountain Areas ANZM, 2021. How to obtain the optional quality mention Mountain Product, [online] Available at: <https://produsmontan.ro/despre-produs-montan> [Accessed 12 April 2021]. 
Santini, F., Guri, F., Gomez, Y. and Paloma, S., 2013. Labelling of agricultural and food products of mountain farming, EUR 25768 EN. Luxembourg (Luxembourg): Publications Office of the European Union, JRC77119. [pdf] Available at: <ftp://ftp.jrc.es/pub/EURdoc/JRC77119.pdf> [Accessed 12 April 2021.

Scarlat, M., 2017. Quality schemes and advantages brought to Romanian producers: Mountain product, Market analysis. AgroTrends, [online] Available at: $<$ https://agrotrends.ro/interviuri/scheme-decalitate-si-avantajele-aduse-producatorilor-romani-produsul-montan> [Accessed 11 April 2021].

Stanciu, S., 2014. Is the tradition profitable for Romanian food producers? Proceedings of The 24th International-Business-Information- Management- Association Conference: Crafting Global Competitive Economies: 2020 Vision Strategic Planning \& Smart Implementation. Milan, Italy, Nov 06-07, 2014. Ed. Soliman, K.S., ISBN:978-0-9860419-3-8, Vols. I-IV, pp.1747-1652.

Stanciu, S., Rizea, R.D. and Ilie A.G., 2015. Study on the Competitiveness of the Romanian Meat Processing Industry. Amfiteatru Economic, 17 (Special Issue 9), pp.1331-1345.

Stanciu, S., Zlati, M.L., Antohi, V.M. and Bichescu, C.I., 2019. The Development Analysis of the Romanian Traditional Product Market Based on the Performance Model for Sustainable Economic Development. Sustainability, 11, Article number: 1123. 